\title{
A CLINICAL STUDY OF VACHADI LEPA IN YOUVANA PIDAKA
}

\author{
Manjunatha $\mathrm{NS}^{1 *}$, Sajitha $\mathrm{K}^{2}$, Ramana $\mathrm{GV}^{3}$
}

\begin{abstract}
Youvana pidaka pidaka is a distressing condition that affects the majority of adolescents, but the impact of Youvana pidaka on the psychological aspects in this age group is poorly understood. The present study titled "A clinical study of lepa in Youvana pidaka" was aimed to observe the efficacy of the trial drug Vachadi lepa in Youvana pidaka. The clinical study was conducted on 40 patients selected randomly. The patients were divided into two groups. Group-A patients were subjected to Vachadi lepa where as group-B patients were given placebo treatment. After dealing with clinical study, observation and results with case discussion was done. In discussion part all the factors and statistical evaluation is given. An attempt was made to explain the efficacy of Vachadi lepa. Among many aetiological factors, unhygienic condition of skin plays an important contributing cause. However age \& sex are having major contribution for the manifestation of disease. Out of 40 patients selected for the study, more number of young adults \& 12 patients were male and 28 were female. It showed the high rate of occurrence and consciousness of this condition in females. CONCLUSION: Vachadi lepa is more effective in Vata and Kapha Prakrithi individuals.
\end{abstract}

Keywords: Lepa, Youvana pidaka, Mukhadooshika, Vachadi Lepa, Acne, Cosmetology, Ayurveda Beauty Care

\section{Introduction:}

A search through the history of mankind reveals an important factor in the form of 'beauty' for which many battles were held. It is the natural instinct of mankind to possess every thing that is beautiful. Many stories of mythological origin depict the involvement of beautiful women in history. It is quite natural that human instinct of looking more and more beautiful lead to innumerable inventions, which form the base for modern cosmetology. Cosmetics are designed to beautify skin, hair or to improve complexion or to modify the overall appearance and presentation. The correction of deformities or treatments described for 'Savarnikarana' etc. can be included in it.

Ayurveda the science of life has its significant contribution in this regard. In the descriptions of 'Dinacharya' and 'Ritucharya' of Swasthavritta descriptions can be found for protecting one's beauty from the day to day stress impacts and seasonal effects on the body. Abyanga; Udvartana; snana; Anulepana (3); are some of the procedures explained in the context of protection from skin disorders and for improving texture and complexion.

The disease 'Youvana pidaka' is aptly named 'Mukhadooshika' as it results in disfigurement of face. The disease produces swellings on the face that resemble like the thorns of the Shalmali (Bombax malabaricum DC) tree (1). They have the predominance of Kapha, Vata and Rakta and occur in adolescence age. The lesions will be filled with meda (fat) according to Vagbhata (2). The disease can be compared with the Acne vulgaris of the present medical literature.

Present treatment options like topical therapies; antimicrobials, hormones, surgery, U-V Irradiations; Intra lesions injections etc. have their own limitations. Ayurvedic management includes periodical Shodhana and lepa for curative and preventive aspect. Acharya Sushruta, Vagbhata have mentioned

1* Corresponding author: Lecturer, Department of Svastavritta, JSS Ayurvedic Medical College, Mysore, Karnataka, India, Tel: +919886728745, E.mail: drmanjunathans@gmail.com, drmanjunathans@rediffmail.com. 2. Prof and HOD, Department of Svastavritta, Sri Sri Ayurvedic Medical College, Bangalore, 3. Research Officer (Ayurveda), NIMHANS (CCRAS), Bangalore. 
'Vachadi lepa' as one such preparation which will significantly cure this malady.

Hence the study effect of Vachadi lepa on Youvana pidaka is planned for trial.

\section{Aims and objectives}

1. To study the effect of Vachadi Lepa in relieving symptoms of Youvana pidaka.

2. To observe the extent of problem of Youvana pidaka in reporting at the skin OPD and IPD of SDM College of Ayurveda and Hospital Hassan.

\section{Materials and methods}

Study Design

This is an experimental study with pretest and post test design. 40 patients of Youvana pidaka were randomly selected for the study from the skin OPD of S.D.M. college of Ayurveda and hospital, Hassan based on the inclusion and exclusion criteria.

\section{Inclusion criteria}

$>$ Patients complaining of Pidaka over the face with history of more than one year.

$>$ Patients between the age group of 17 and 30 years.

\section{Exclusion criteria}

$>$ Patients having Pidaka of other Kshudra Roga and Kusta.

$>$ Patients who are not able to follow the prescribed treatment.

$>$ Patients having Pidaka on places other than face.

\section{Assessment Criteria}

Assessment of the patients was done based on the relief in the symptomatic parameters. The symptoms and the grading are as follows.

\section{Oiliness of the face}

Normal skin $\quad-0$

Requires face washing once in 3-4 - 1 hours
Requires face washing once in 1-2 - 2 hours

Feels oily even after face wash $\quad-3$

\section{Size of the Pidaka}

No Pidaka

Less than $5 \mathrm{~mm}$

In between 5 to $10 \mathrm{~mm} \quad-\quad 2$

More than $10 \mathrm{~mm}$

$$
\begin{array}{ll}
- & 0 \\
- & 1 \\
- & 2
\end{array}
$$

\section{Number of scars}

No Scars

$-0$

Less than 10 on one side

$-1$

In between 11 to 30 on one side $\quad-2$

More than 30 on one side

$-3$

\section{Vedana}

No tenderness $\quad-0$

Pain on deep pressure over the - 1

Pidaka

Pain on touch $\quad-\quad 2$

Pain without touch $\quad-3$

\section{Number of pidaka}

$\begin{array}{lll}\text { No Pidaka } & - & 0 \\ \text { Less than } 10 \text { on one side } & - & 1 \\ \text { In between } 11 \text { to } 30 \text { on one side } & - & 2 \\ \text { More than } 30 \text { on one side } & - & 3\end{array}$

The patients thus selected were divided into two groups of 20 patients each. Group A (experimental group) patients were given Vachadi lepa for external application and group B (control group) patients were given placebo tablets twice daily.

\section{Materials Required for the Study}

1. Vachadi Lepa

2. Placebo capsules, filled with $500 \mathrm{mg}$ of starch powder

3. Tissue paper, to assess the Snigdhata (oiliness) of skin

4. Scale, to measure the size of Pidaka

\section{Vachadi lepa}

Drugs: - (6)

1. Rhizome of vacha (Acorus calamus Linn.) 
2. Bark of Lodhra (Symplocus racemosa Roxb.)

3. Sarshapa Beeja (Brassica nigra Linn.)

4. Saindava Lavana

\section{Method of preparation of Lepa}

The above mentioned drugs are powdered individually in a khalvayantra to get fine powder. Equal quantities of powders of individual drugs are taken in a vessel and mixed with normal water to make them into a lepa or paste form. This lepa is applied over the face.

\section{Method of application of Lepa:}

It is having three steps:

\section{Poorva karma:}

The patient was asked to wash the face with normal water prior to application of lepa.

\section{Pradhana Karma:}

Required quantity of choorna was taken and normal water was added in sufficient amount to convert the choorna in to Lepa form.

The patients were advised to apply Lepa in the opposite direction to hair roots, all over the face. (5)

The Lepa was applied with a uniform thickness of one fourth of once own thumb width (about 1/4th of an inch).(5)

Lepa was applied in morning (between 7 and $10 \mathrm{am}$ ) and it should be applied over the face for at least forty five minutes to one hour or until lepa gets dried up).

\section{Paschat Karma:}

After the drying up of the lepa, the patients were asked to wash the face with normal water and were advised to follow Pathya.

\section{Follow-up}

Patients of both the groups were asked to visit once in a week for the 15 days of treatment and for the next 30 days to assess the parameters.

\section{OBSERVATIONS AND RESULTS}

A total of 40 patients were selected for the study. Among them majority of the patients were from the age groups 20-22 (45\%) followed by the age groups 17-19 $(30 \%)$ (Table: 1). Female patients were $70 \%$ and male patients were $30 \%$. (Table: 2). Among the total number of patients, 29 $(72.50 \%)$ were having oily skin. (Table: 3 ) and the most predominant dosha in most of the patient is kapha $22(55 \%)$.

Table 1: Showing distribution of patients according to Age

\begin{tabular}{|l|l|l|}
\hline Age in years & Total No. of Patients & Total \% \\
\hline $17-19$ & 12 & 30.00 \\
\hline $20-22$ & 18 & 45.00 \\
\hline $23-25$ & 04 & 10.00 \\
\hline $26-28$ & 03 & 07.50 \\
\hline 29 and above & 03 & 07.50 \\
\hline Total & 40 & 100 \\
\hline
\end{tabular}

Table 2: Showing distribution of patients based on Sex

\begin{tabular}{|l|l|l|l|l|l|l|}
\hline Sex & Group A & \% & Group B & $\%$ & $\begin{array}{l}\text { Total No. } \\
\text { Of Patients }\end{array}$ & Total \% \\
\hline Male & 04 & 20 & 08 & 40 & 12 & 30 \\
\hline Female & 16 & 80 & 12 & 60 & 28 & 70 \\
\hline
\end{tabular}


Table 3: Table showing the distribution of patients based on the skin type

\begin{tabular}{|l|l|l|l|l|l|l|}
\hline Skin type & Group A & $\mathbf{\%}$ & Group B & $\mathbf{\%}$ & $\begin{array}{l}\text { Total No. } \\
\text { Of Patients }\end{array}$ & Total \% \\
\hline Normal & 01 & 05 & 06 & 30 & 05 & 17.50 \\
\hline Rooksha (Dry) & 02 & 10 & 02 & 10 & 06 & 10.00 \\
\hline Snighda (Oily) & 17 & 85 & 12 & 60 & 29 & 72.50 \\
\hline Total & 20 & & 20 & & 40 & \\
\hline
\end{tabular}

Table 4: Showing distribution of patients based on Dosha

\begin{tabular}{|l|l|l|l|l|l|l|}
\hline Dosha & Group A & $\mathbf{\%}$ & Group B & $\%$ & $\begin{array}{l}\text { Total No. Of } \\
\text { Patients }\end{array}$ & $\begin{array}{l}\text { Total } \\
\%\end{array}$ \\
\hline Vata & 02 & 10 & 08 & 40 & 10 & 25.00 \\
\hline Pitta & 06 & 30 & 02 & 10 & 08 & 20.00 \\
\hline Kapha & 12 & 60 & 10 & 50 & 22 & 55.00 \\
\hline Total & 20 & & 20 & & 40 & \\
\hline
\end{tabular}

\section{Results:}

The results obtained from the study show a marked difference in the relief of symptoms in experimental and control groups. Experimental group patients showed highly significant ('p' value $<0.0001)$ results in the relief of the all the symptoms except the number of scars, whereas the control group did not show significant results in any of the symptom except the skin type. Thus it is clear from the study that the drug Vachadi lepa helps in the management of Youvana pidaka.

Table 5: Showing distribution of results of group-A

\begin{tabular}{|l|l|l|l|l|l|}
\hline Value name & Skin type & Size of Pidaka & No. of Scar & Vedhana & No. of Pidaka \\
\hline BTM & 1.733 & 1.266 & 1.333 & 0.866 & 1.400 \\
\hline ATM & 0.800 & 0.600 & 1.000 & 0.060 & 0.600 \\
\hline DM & 0.933 & 0.466 & 0.333 & 0.806 & 0.800 \\
\hline \% of improvement & 53.75 & 43.39 & 15.38 & 93.02 & 57.14 \\
\hline SD & 0.249 & 0.490 & 0.471 & 0.400 & 0.541 \\
\hline SE & 0.060 & 0.120 & 0.211 & 0.103 & 0.139 \\
\hline t - value & 15.65 & 3.833 & 1.572 & 7.802 & 5.75 \\
\hline p - value & $<0.001$ & $<0.001$ & $>0.100$ & $<0.001$ & $<0.001$ \\
\hline
\end{tabular}

BTM $=$ Before treatment mean

$\mathrm{ATM}=$ After treatment mean

$\mathrm{DM}=$ Difference of mean $\quad \mathrm{SD}=$ Standard deviation $\quad \mathrm{SE}=$ Standard error

Table 6: Showing distribution of results of group-B

\begin{tabular}{|l|l|l|l|l|l|}
\hline Value name & $\begin{array}{l}\text { Skin } \\
\text { type }\end{array}$ & $\begin{array}{l}\text { Size Pidaka } \\
\text { Pre }\end{array}$ & $\begin{array}{l}\text { No. of } \\
\text { Scar }\end{array}$ & Vedhana & $\begin{array}{l}\text { No. of } \\
\text { Pidaka }\end{array}$ \\
\hline BTM & 1.133 & 1.266 & 1.400 & 0.533 & 1.666 \\
\hline ATM & 0.666 & 1.200 & 1.333 & 0.400 & 1.600 \\
\hline DM & 0.466 & 0.066 & 0.067 & 0.133 & 0.067 \\
\hline \% of improvement & 41.50 & 04.76 & 05.00 & 24.52 & 03.61 \\
\hline SD & 0.489 & 0.257 & 0.249 & 0.339 & 0.249 \\
\hline SE & 0.128 & 0.060 & 0.065 & 0.113 & 0.065 \\
\hline t - value & 3.622 & 1.00 & 1.015 & 1.173 & 1.015 \\
\hline
\end{tabular}


$\mathrm{p}$ - value

$<0.005$

$>0.30$

$>0.30$

$>0.20$

$>0.30$

\section{DISCUSSION ON RESULTS}

Youvana pidaka is a most common disorder in the adolescent age because of the improper management of hygiene. This causes disfiguration of the body especially on the face. This proves to be a major cosmetic problem. This can be compared with the disease Acne vulgaris of the present medical literature.

In the present study conducted on 40 patients to know the efficacy of the Vachadi lepa it has been observed that the drug has shown statistically significant results in the management of Youvana pidaka. It was useful especially for the patients having the predominance of kapha and vata dosha. This is because of the ushna veerya of the drugs used in the formulation. The drugs used have the properties of vedana stahapana, shotha hara, vrana ropana and shodhana which help as cleansing, anti-microbial and antiinflammatory agents.

In the pitta dosha predominant cases it was observed that the application of the lepa caused mild irritation indicating the pitta prakopa gunas of the drugs. So the drug is to be used with caution in pitta prakruti patients.

\section{CONCLUSION}

Overall effect of the Vachadi lepa proved to be significant in the management of the Youvana pidaka when compared to the results of the placebo drug.

Further research on large number of patients with this formulation is needed to prove the positive results of the formulation in the cases of Youvana pidaka.

\section{References}

1. Kaviraj Ambhikadutta Shastri. Sushruta's Sushruta sahmita, nidana stana translation. Varanasi; Chaukambha Sanskrit Sanstana; 287.

2. Srikantamurthy KR. Vagbhata's Astanga Hrudaya, uttara stana 31/5, VolIII Translation. Varanasi, Krishnadas academy; 1995, 291

3. Raja Radhakanta Deva. Shabda kalpa druma, part IV. Nag Publishers; p68

4. Kaviraj Ambhikadutta Shastri. Sushruta's Sushruta sahmita, Sutra stana translation. Varanasi; Chaukambha Sanskrit Sanstana; 74-75.

5. Kaviraj Ambhikadutta Shastri. Sushruta's Sushruta sahmita, Cikitsa stana translation. Varanasi; Chaukambha Sanskrit Sanstana; 95. 
Figure 1:

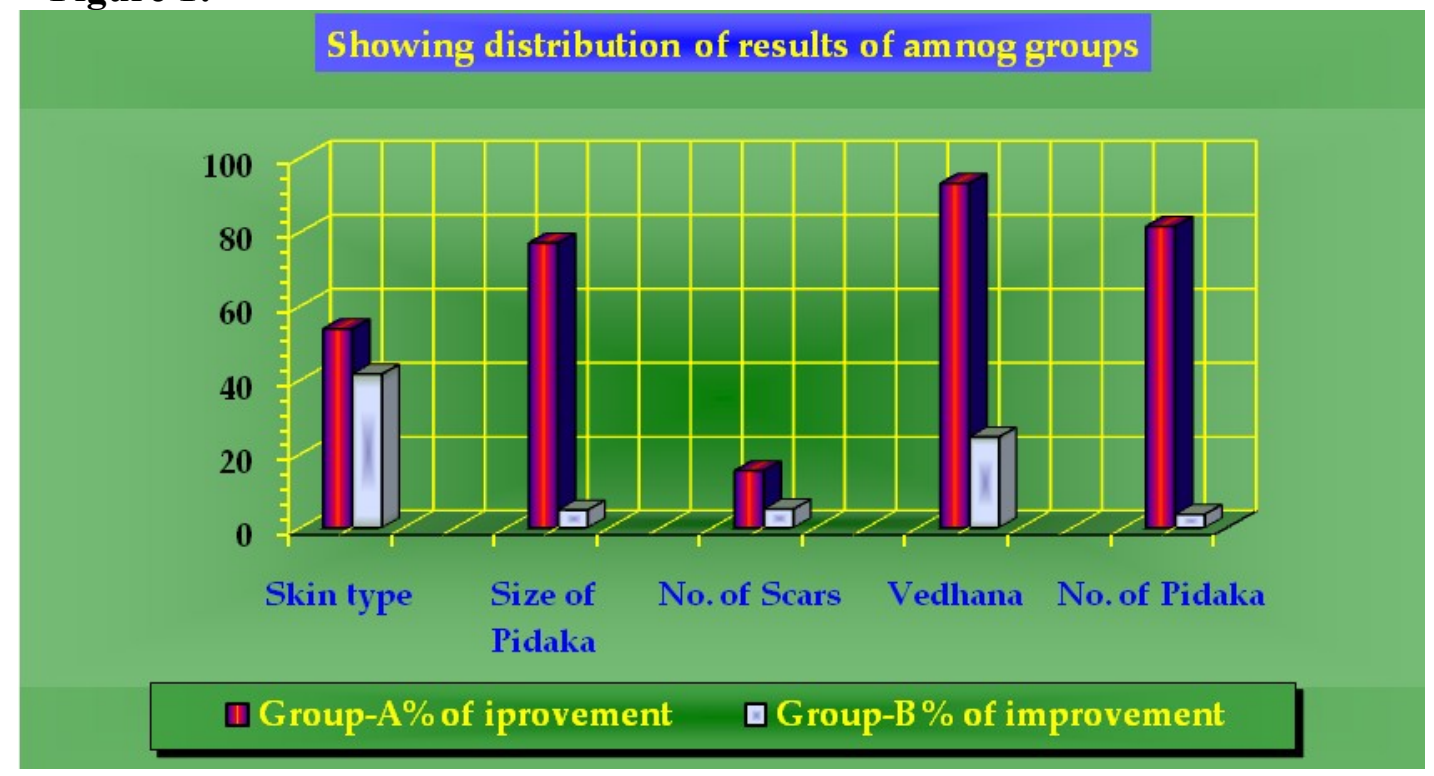

Figure 2:

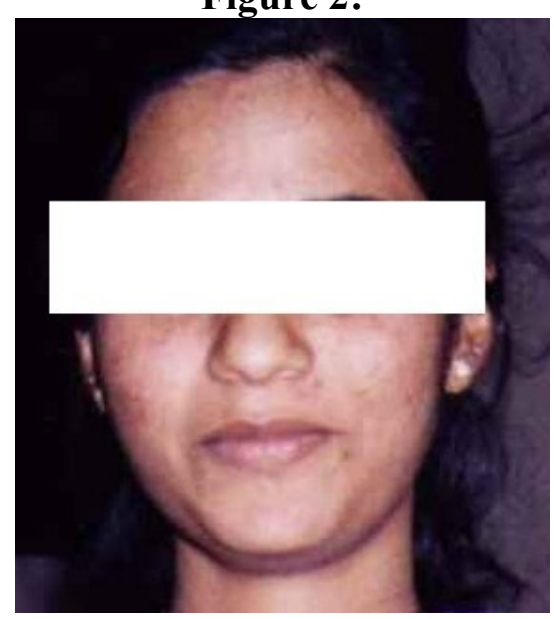

Before Treatment

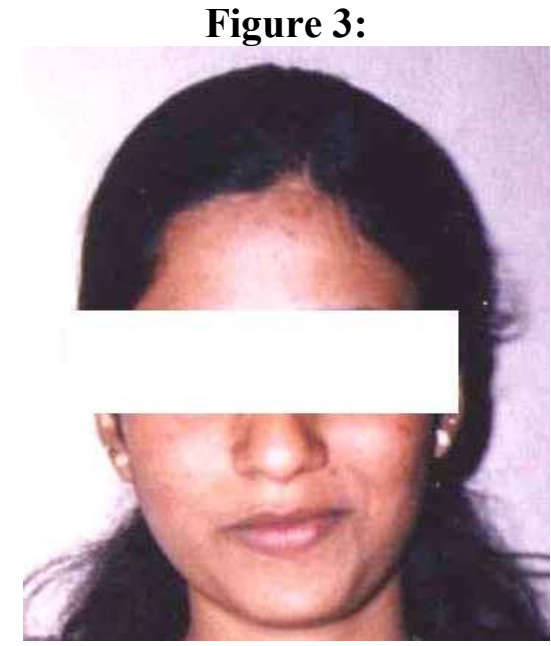

After Treatment

Figure 4:

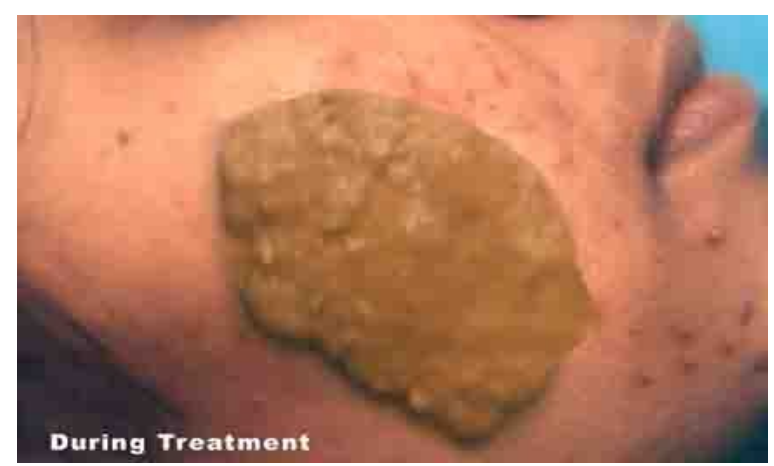

During Treatment 
Figure 5:

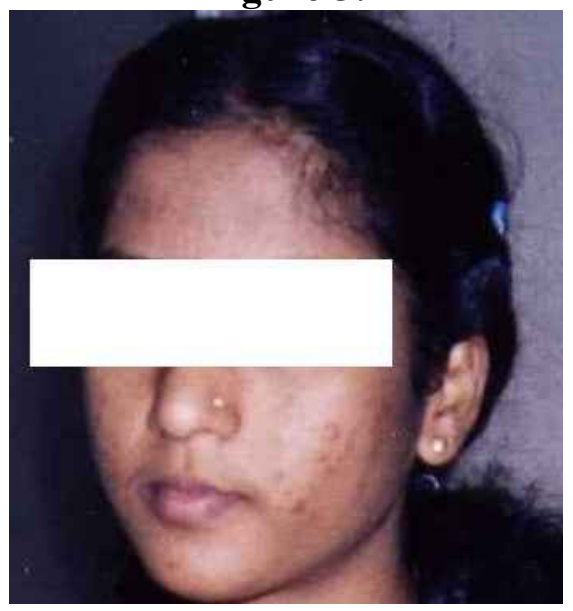

Before Treatment
Figure 6:

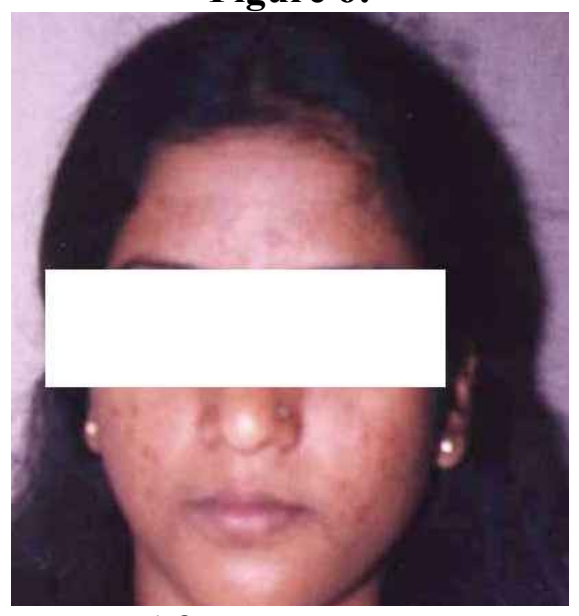

After Treatment 